Copyright (C) 2018 by Academic Publishing House Researcher

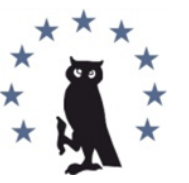

Published in the Russian Federation

European Researcher. Series A

Has been issued since 2010.

ISSN 2219-8229

E-ISSN 2224-0136

2018, 9(3): 259-266

DOI: $10.13187 /$ er.2018.3.259

www.erjournal.ru

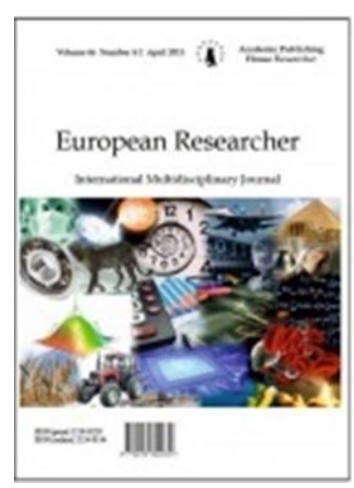

\title{
Investigation of the Attitudes of Primary and Secondary School Students Toward Music Lessons Depending on Some Variables
}

\author{
Gizem Saygilii a , * \\ ${ }^{a}$ Karamanoğlu Mehmetbey University, Karaman, Turkey
}

\begin{abstract}
The aim of this study is to investigate the attitudes of primary and secondary school students toward music lesson by variables. The study was done to 340 female and 334 male, a total of 674 , students who are studying in different schools in Isparta. "Müzik Dersine Yönelik Tutum Ölçeği (Attitude Scale for Music Lessons)", which was formed by Özmenteş (2006), was used to determine the attitude of the participants towards music lessons. One Sample Kolgomorov-Smirnov, Mann Whitney U, Kruskal Wallis $\mathrm{H}$ tests were conducted in SPSS 15.0 for Windows program and descriptive statistics were used to analyze the data. As a result of the study, it was determined that there is not a significant difference in the level of attitude of the participants towards music lessons depending on their gender, grade, educational status of their parents, and the number of individuals in their family ( $p>0.05)$. On the other hand, it was observed that some participants agree the considerations about music class in different levels.
\end{abstract}

Keywords: primary school, music education, attitude.

\section{Introduction}

Music education is a subject that humankind has been curious about since the early ages. Many thinkers and scholars approached music with its spiritual and philosophical extents. Having assigned various meanings and being an integral part of life; music has a great influence in the world of human beings. Music, which is an important part of the life of human beings, is also an educational appliance since it has a big role in the growth of children both physically and mentally. Therefore, music education is to be considered as an important factor to raise qualified individuals, especially in childhood (Ergen, Bilen, 2010). Also, it is known that rhythm education, which is a part of music education, supports psychomotor improvement of children (Dündar, 2003).

In order to succeed in music education, there is a need for an education program that contains the assessment and evaluation program for the behavior that is to be provided to the students. Regulations on music education are made in 1968, 1984, and 1994, in Turkey. The new music education program, which was come into operation in 2005-2006, was made by constructivist perspective (Kırmızıbayrak, 2012). Form teachers perform music education in the classes that are in primary school level. In the classes that are in secondary school level, branch teachers perform music education (Bilgin, Şaktanl, 2008). General music education consists of these aspects; musical hearing and voice education, instrument education, creativity education, rhythm education and basic musical knowledge education (Kutluk, 2010). Additionally, music

\footnotetext{
${ }^{*}$ Corresponding author

E-mail addresses: gizemsaygili@kmu.edu.tr (G. Saygilii)
} 
education is done on the basis of making music, in Turkey. Teachers play instruments in the class on this basis (Uluocak, Tufan, 2010).

The attitude of students toward lessons and learning is better when the lessons are taught individually. The main reason for this phenomenon is the teachers and students communicate better when there are less people in the class. In many institutions that provide fine arts education like music education individual education programs are frequently applied (Yalçınkaya, Eldemir, 2013). However, there are a huge number of problems that is encountered in schools about music education. Although the general conditions about the education are satisfied, one of the main problems that are encountered in schools is that the proper education is not done considering the voice of the students (Noyan, 2012). Besides, type and feature of the materials that are used in music education cause some negative outcomes. For instance, flute is widely used in Turkey for music education since it is relatively cheap, portable and it does not have accord problems. Although it is possible to play the tune with flute, teaching the songs with flute is hard (Küçükosmanoğlu, Çakırer, 2012).

Attitude is a mental, emotional, and behavioral pre-reaction tendency which is organized based on the experience, knowledge and emotions of the individuals against the individuals themselves or against a matter, a social issue or an action which is in the environment of the individual (İnceoğlu, 2010). In social sciences, attitude is considered as a concept that has not been defined yet (Şeker, Saygl, 2013). Attitude of an individual is a phenomenon that is learned afterwards, and may vary in socialization process by the time (Levent, Umuzdaş, 2013). Therefore, attitudes come off by experience and may be formed by time (Gömleksiz, 2003).

Primary schools students are children that are in their playing ages. In this period, music education contributes these students to improve their creativities, productivities; to explore their environments; and to make them participant individuals (Helvacl, 2012). Hence, it is needed to be ensured that the attitudes of primary and secondary school students toward music education need to be improved and they are to be provided to benefit from music education. Because, attitude towards music education is one of the main factors that influence the success of the students in music education (Varıs, Cesur, 2012). In order to provide this, firstly, the attitudes of students toward music education and the factors that influence the attitudes toward music education need to be determined. Therefore, in this study, it is aimed to investigate the level of attitudes of primary and secondary school students toward music education depending on some variables.

\section{Materials and Methods}

2.1. The Model of the Study: This study, which aims to investigate the level of attitude of primary and secondary school students towards music education depending on some variables as; the grade of the students, educational status of their parents, genders of the students, and number of individuals in their family; is a descriptive study that is properly modeled in general scanning model (Karasar, 2005: 77).

2.2 Research Group: A total of 685 students, who are studying at various elementary schools in Isparta, participated to the study voluntarily. Descriptive information about the participants is given in Table 1.

Table 1. Descriptive statistics about participants

\begin{tabular}{|c|c|c|c|}
\hline Variables & Sub variables & $\mathbf{f}$ & $\%$ \\
\hline \multirow{2}{*}{ Gender } & Female & 340 & 50.4 \\
\hline & Male & 334 & 49.6 \\
\hline \multirow{3}{*}{ Grade } & $2-4$ & 60 & 8.8 \\
\hline & $5-6$ & 250 & 36.9 \\
\hline & $7-8$ & 368 & 54.3 \\
\hline \multirow{2}{*}{$\begin{array}{c}\text { Educational status of } \\
\text { the father of } \\
\text { participants }\end{array}$} & $\begin{array}{l}\text { Elementary school } \\
\text { graduate or below }\end{array}$ & 137 & 21.9 \\
\hline & $\begin{array}{l}\text { High school } \\
\text { graduate }\end{array}$ & 156 & 24.9 \\
\hline
\end{tabular}




\begin{tabular}{|c|c|c|c|}
\hline & $\begin{array}{c}\text { University } \\
\text { graduate or above }\end{array}$ & 333 & 53.2 \\
\hline \multirow{3}{*}{$\begin{array}{c}\text { Educational status of } \\
\text { the mother of } \\
\text { participants }\end{array}$} & $\begin{array}{l}\text { Elementary school } \\
\text { graduate or below }\end{array}$ & 201 & 31.1 \\
\hline & $\begin{array}{l}\text { High school } \\
\text { graduate }\end{array}$ & 200 & 30.9 \\
\hline & $\begin{array}{c}\text { University } \\
\text { graduate or above }\end{array}$ & 246 & 38.0 \\
\hline \multirow{2}{*}{$\begin{array}{l}\text { Number of individuals } \\
\text { in the family }\end{array}$} & $2-4$ & 444 & 66.4 \\
\hline & $5-6$ & 225 & 33.6 \\
\hline
\end{tabular}

2.3 Data Acquisition: "Müzik Dersine Yönelik Tutum Ölçeği (Attitude Scale for Music Lessons)", which was formed by Özmenteş (2006), was used as the data collection tool. Attitude Scale for Music Lessons is a one dimensional scale that consists of 20 items (12 positive, 8 negative). Cronbach's Alpha reliability coefficient of the scale was found as 0.86 . The items in the scale were graded as: Strongly agree (5 points), Agree (4 points), Slightly Agree (3 points), Disagree (2 points), Strongly Disagree (1 point). The possible results that can be obtained from the scale vary from 20 points to 100 points. Increasing points that is obtained from the scale show that the attitude towards music education is high.

2.4 Analysis of Data: The analysis of the data that is acquired from the study was done by using the program SPSS 15.ofor Windows. By using OneSampleKolmogorov-Smirnov test, the data were investigated whether they show a normal distribution; and, it was observed that the data do not show a normal distribution. Therefore, nonparametric tests were used to make comparisons. Mann Whitney U test was used to make comparisons on gender and on the number of individuals in families. Kruskal Wallis $\mathrm{H}$ test was used to make comparisons on gender and on the educational statues of the parents of the participants. Descriptive statistics (mean, standard deviation, frequency) were also used.

\section{Findings}

Table 2. Average points that participants obtained from the scale

\begin{tabular}{|c|c|c|}
\hline $\mathbf{N}$ & $\mathbf{X}$ & $\mathbf{S s}$ \\
\hline 685 & 42.01 & 17.92 \\
\hline
\end{tabular}

Considering the maximum point that can be obtained from the scale is 100, the attitude of the participants of this study can be defined as average.

Table 3. Comparison of the attitude of the participants toward music education depending on some variables

\begin{tabular}{|c|c|c|c|c|c|c|}
\hline Variables & Sub variables & $\mathbf{N}$ & $\mathbf{X}$ & Ss & $\mathbf{Z} / \mathbf{X}^{\mathbf{2}}$ & $\mathbf{P}$ \\
\hline \multirow{2}{*}{ Gender } & Female & 340 & 40.96 & 17.47 & \multirow[b]{2}{*}{$-1.309^{z}$} & \multirow{2}{*}{.191} \\
\hline & Male & 334 & 42.90 & 18.34 & & \\
\hline \multirow{3}{*}{ Grade level } & $2-4$ & 60 & 38.97 & 16.63 & \multirow{3}{*}{$4 \cdot 334^{\mathrm{x} 2}$} & \multirow{3}{*}{.115} \\
\hline & $5-6$ & 250 & 40.81 & 17.50 & & \\
\hline & $7-8$ & 368 & 43.28 & 18.30 & & \\
\hline \multirow{2}{*}{$\begin{array}{l}\text { Number of individuals } \\
\text { in the family }\end{array}$} & $2-4$ & 444 & 41.70 & 17.80 & \multirow{2}{*}{$-.387^{z}$} & \multirow{2}{*}{.699} \\
\hline & $5-6$ & 225 & 42.40 & 17.82 & & \\
\hline $\begin{array}{c}\text { The educational status } \\
\text { of the father of } \\
\text { participants }\end{array}$ & $\begin{array}{c}\text { Elementary } \\
\text { school graduate } \\
\text { or below } \\
\end{array}$ & 137 & 42.33 & 17.28 & $.608^{x 2}$ & .738 \\
\hline
\end{tabular}




\begin{tabular}{|c|c|c|c|c|c|c|}
\hline & $\begin{array}{l}\text { High school } \\
\text { graduate }\end{array}$ & 156 & 42.79 & 18.77 & & \\
\hline & $\begin{array}{l}\text { University } \\
\text { graduate or above }\end{array}$ & 333 & 41.53 & 17.94 & & \\
\hline \multirow{3}{*}{$\begin{array}{l}\text { The educational status } \\
\text { of the mother of } \\
\text { participants }\end{array}$} & $\begin{array}{l}\text { Elementary } \\
\text { school graduate } \\
\text { or below }\end{array}$ & 201 & 41.32 & 17.26 & \multirow{3}{*}{$.498^{\times 2}$} & \multirow{3}{*}{.780} \\
\hline & $\begin{array}{l}\text { High school } \\
\text { graduate }\end{array}$ & 200 & 42.80 & 18.42 & & \\
\hline & $\begin{array}{c}\text { University } \\
\text { graduate or above }\end{array}$ & 246 & 42.18 & 18.21 & & \\
\hline
\end{tabular}

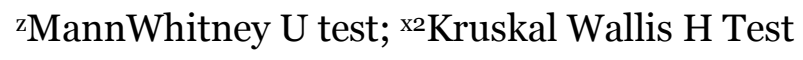

When the table is analyzed it is observed that the attitude level of male participants is greater than female participants; the attitude level of the participants that are in $7^{\text {th }}$ and $8^{\text {th }}$ grades is greater than $2^{\text {nd }}$ and $4^{\text {th }}$, and $5^{\text {th }}$ and $6^{\text {th }}$ grade students; the attitude level of the participants that have 5 or 6 people in their family is greater than the participants that have between 2 and 4 people in their family. Also, the attitude level of participants that the educational status of their father is high school graduate, and the attitude level of participants that the educational status of their mother is high school graduate are greater than the others. Although there are differences for the results depending on these variables; statistically, there is not a significant difference depending on these variables $(p>0,05)$.

Table 4. Frequency and percentage distribution of the answers that the participants gave about music education

\begin{tabular}{|c|c|c|c|}
\hline Variables & 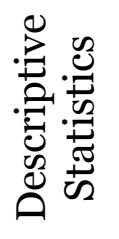 & $\stackrel{\mathscr{a}}{\sim}$ & $\stackrel{\circ}{z}$ \\
\hline \multirow{2}{*}{ Is there anyone in your family who is interested in music? } & $\mathrm{f}$ & 367 & 310 \\
\hline & $\%$ & 54.2 & 45.8 \\
\hline Do you play any instrument? & $\mathrm{f}$ & 458 & 213 \\
\hline \multirow{2}{*}{$\begin{array}{l}\text { Would you choose to attend Fine Arts High School, Department of Music, } \\
\text { after the graduation? }\end{array}$} & $\frac{\%}{f}$ & $\frac{68.3}{477}$ & $\frac{31.7}{184}$ \\
\hline & $\%$ & 72.2 & 27.8 \\
\hline \multirow{2}{*}{ Do you think that you are talented at music? } & $\mathrm{f}$ & 544 & 138 \\
\hline & $\%$ & 79.8 & 20.2 \\
\hline \multirow{2}{*}{$\begin{array}{c}\text { Do branch teachers need to perform music classes in 1st 2nd } 3 \text { rd and } 4 \text { th } \\
\text { grades? }\end{array}$} & $\mathrm{f}$ & 570 & 98 \\
\hline & $\%$ & 85.3 & 14.7 \\
\hline \multirow{2}{*}{ Do you think that songs and topics of the textbook are interesting? } & $\mathrm{f}$ & 572 & 110 \\
\hline & $\%$ & 83.9 & 16.1 \\
\hline \multirow{2}{*}{ Do you give importance to music lessons as much as you do to other lessons? } & $\mathrm{f}$ & 592 & 80 \\
\hline & $\%$ & 88.1 & 11.9 \\
\hline \multirow{2}{*}{$\begin{array}{c}\text { Does your family give importance to music lessons as much as they do to } \\
\text { other lessons? }\end{array}$} & $\mathrm{f}$ & 538 & 139 \\
\hline & $\%$ & 79.5 & 20.5 \\
\hline \multirow{2}{*}{$\begin{array}{c}\text { Does your teacher give importance to music lessons as much as they do to } \\
\text { other lessons? }\end{array}$} & $\mathrm{f}$ & 574 & 102 \\
\hline & $\%$ & 84.9 & 15.1 \\
\hline \multirow{2}{*}{$\begin{array}{l}\text { Does getting a low grade from music make you upset as much as getting a low } \\
\text { grade from any other class? }\end{array}$} & $\mathrm{f}$ & 538 & 133 \\
\hline & $\%$ & 80.2 & 19.8 \\
\hline \multirow{2}{*}{ Do you feel that you succeed at other classes when you succeed at music? } & $\mathrm{f}$ & 446 & 238 \\
\hline & $\%$ & 65.2 & 34.8 \\
\hline \multirow{2}{*}{$\begin{array}{l}\text { Would you like to attend the music classes in a class that with musical } \\
\text { instruments? }\end{array}$} & $\mathrm{f}$ & 413 & 256 \\
\hline & $\%$ & 61.7 & 38.3 \\
\hline
\end{tabular}




\begin{tabular}{|c|c|c|c|}
\hline \multirow{2}{*}{ Do you think that it is sufficient to get the music lessons 1 hour in a week? } & $\mathrm{f}$ & 455 & 196 \\
\cline { 2 - 4 } & $\%$ & 69.9 & 30.1 \\
\hline \multirow{2}{*}{ Is music lesson need to be elective in elementary school? } & $\mathrm{f}$ & 218 & 464 \\
\cline { 2 - 4 } & $\%$ & 32.0 & 68.0 \\
\hline \multirow{2}{*}{ Would it be better to have a teacher whose branch is musical education? } & $\mathrm{f}$ & 588 & 89 \\
\cline { 2 - 4 } & $\%$ & 86.9 & 13.1 \\
\hline Would you like to be a music teacher in the future? & $\mathrm{f}$ & 81 & 595 \\
\hline
\end{tabular}

In the families of more than half of the participants, there are individuals who are interested in music. $68.3 \%$ of the participants play a musical instrument. A significant portion of the participants consider attending Music Department in high school. Approximately, every 4 participants out of 5 thinks that branch teacher should perform music lessons in $1^{\text {st }}, 2^{\text {nd }}, 3^{\text {rd }}$ and $4^{\text {th }}$ grades; and they think that the songs and topics of the textbook are interesting. Almost all of the participants give importance to the music lessons as much as they do to other lessons, and they think that their families and their teachers give importance to the music lessons as much as they do to other lessons. Approximately, every 4 participants out of 5 think that getting a low grade from music make them upset as much as getting a low grade from any other class; and approximately two-third of the participants feel that they succeed at other classes when they succeed at music. $61.7 \%$ of the participants would like to attend the music lessons in a class with musical instruments. More than two-third of the participants think that attending to music lessons one hour in a week is sufficient; and one-third of the participants think that music lessons should be an elective course. The majority of the participants think that branch teachers should perform music lessons, and only $12 \%$ of the participants would like to be a music teacher in the future.

\section{Discussion}

The effect of gender factor to primary and secondary school students on music education is an issue that to be emphasized (Rife et al., 2001). It was observed that there is not a significant difference in the attitude of the participants toward music education depending on their genders. In some studies, it was also observed that the gender factor does not affect the attitude of the students toward music education in educational environment (Koca, 2013). Contrarily, in some other studies, it was observed that gender factor is an influencing factor on the level of attitude of individuals toward music education (Otacıŏ̆lu, 2007; Nacakcı, 2006; Uluocak, Tufan, 2011; Varış, Cesur, 2012). Considering the attitude is an important element for learning (Ergen, Bilen, 2010), it is very important to determine the factors that influence the attitude of female and male students toward music education. Although it was observed in this study that the gender of the students does not have a significant effect on the attitude of these students toward music education, it should not be forgotten that the needs and the interest of female and male students differ in many subjects.

It was observed that there is not a significant difference in the attitude of the participants toward music education depending on their grade levels. Although it was observed in this study that the grade level of the students does not have a significant effect on the attitude of these students toward music education, Nacakcı (2006) indicates that there should be a program developed in elementary schools, considering the grade levels of the students in order to improve the level of attitude of the students toward music education. Therefore, in order to obtain a difference in the level of attitudes of the elementary school students toward music education depending on their grade levels; firstly, the present music education programs should be reviewed. In a similar study which was done to elementary school students, it was stated that the level of attitude of the students toward music education depending on their grade levels differs; and, the main reason for this phenomenon was stated as the interests of the students differ depending on their grade levels. As a consequence of that study, it was emphasized that the music classes should be organized by considering the age and grade level of the students (Otacioğlu, 2007).

It was observed that there is not a significant difference in the attitude of the participants toward music education depending on the number of individuals in their families. Additionally, in the families of most of the participants there are individuals that are interested in music. Although the majority of the individuals who are in the families of the participants are interested in 
music, it was observed that the number of individuals in the families of the participants is not a key factor that affects the level of attitude of the students toward music education. However, in some studies, rather than the number of individuals in the families of the students, the musical atmosphere of the family environment is a significant element to influence the level of attitude of the students toward music education. According to the study that was done by Özmenteş (2012), it was determined that the musical atmosphere of the home environments of the elementary school students influences the level of attitudes of these students toward music education.

It was observed that there is not a significant difference in the attitude of the participants toward music education depending on the educational status of their parents. In some similar studies, it was determined that that there is not a significant difference in the attitude of the participants toward music education depending on the educational status of their parents (Nacakcl, 2006; Uluocak, Tufan, 2011). According to the study that was done by Özmenteş (2012), it was stated that the having parents who are interested in music, having parents who motivate their children to do some musical activities, and having parents who cooperate with school and music teachers influence the level of attitude of the students toward music education positively. Although it was observed in this study that the educational status of the parents of the students does not have a significant effect on the attitude of these students toward music education, parents may affect the level of attitudes of the students toward music education in different ways.

It was determined that the level of attitude of the participants toward music education is average, and most of these participants (68.3\%) can play at least one musical instrument. Also, it is observed that the majority of the students want to continue their education in a school that provides musical education, and they think that they need to get their music grades as high as possible. It is prior to provide a proper environment to have the children playing a musical instrument (Uluocak, Tufan, 2011). According to the study that was done by Nacakc1 (2006), primary school students are enthusiastic to play a musical instrument. According to various studies, the level of attitude of the students toward music education is generally positive (Koca, 2013; Babacan et al., 2011; Uluocak, Tufan, 2011). The level of attitude of the students toward music education is rather important in order to succeed in music classes. The desired success in music classes can be achieved by the program that is provided according to the interests of the students, and a program that increases the level of attitude towards the classes (Nacakc1, 2006). It can be stated that having an average value of the level of attitude of the participants towards music classes prevents the students to get adequate efficiency from the classes.

It was determined that the majority of the participants find the songs and the topics of the textbook interesting, and they think that branch teacher should perform music classes. Nacakc1 (2006) stated that the attitudes are the features that change by time; therefore, beginning from primary school, having branch teachers to perform the music classes and providing the usage of any kind of musical instrument in the class would increase the attitude of the students toward music education. Additionally, in that study, it was stated that the opinions of the students should be received while organizing and improving the educational programs on music education. In the study that was done by Otacıoğlu (2007), it was determined that while the level of attitude of the elementary school students towards music education is increased, the success in music classes increases accordingly. Therefore, it can be stated that the usage of proper educational materials and having branch teachers performing music classes would increase both the attitude of the students towards music education, and the success of the students in music classes.

It was determined that the majority of the students think that the classes should be carried out in a classroom that has musical instruments, and they think that the weekly course hours are not sufficient. Also, it was determined that the teachers and the parents of the students give importance to music classes as much as they do to the other classes. In a similar study that was done by Koca (2013), it was determined that the students think for the music classes, the course hours are not sufficient. In the same study, it was emphasized that the weekly course hours for music classes are not sufficient. Since music education has a critical importance for the elementary school students (Uluocak, Tufan, 2011), it is considered to increase the weekly course hours for music classes in elementary school curriculum as a significant factor for the students. Moreover, it is a natural approach for the students to want to music classes to be performed in a classroom with musical instruments. In some studies it was observed that it is a requirement to have different musical instruments in music classes, and the musical instruments that the 
teachers play in the classes influences the level of attitude of the students toward music education (Levent, Umuzdaş, 2013).

According to the study, the majority of the participants think that music classes should be elective courses. According to the study that was done by Varış and Cesur (2012), choosing the music classes as a must or an elective course is a factor that influences the level of attitudes of the students toward music education. It should not be forgotten that as long as the music classes remain as a must course in the curriculum, the students have a low attitude toward music education will affect the attitude of the other students toward music education. Therefore, changing the music classes as elective courses would contribute to attendance to the classes only by the students that have high attitude toward music education, and to increase the efficiency of the classes both for the students and the teachers.

\section{Conclusion}

The level of attitude of the primary and secondary school students toward music education was found to be average, and there is not a significant difference that was observed depending on the grade level of the students, gender of the students, educational status of their parents, and the number of individuals in their families. In addition, it was observed that the majority of the participants can play a musical instrument, want to attend to a music department after primary education, state that there is a need for branch teachers to perform music classes, and find songs and topics of the textbook interesting. Moreover, it was determined that the most of the students want to get high grades from music class, think that the classes should be performed in a classroom with musical instruments, find the weekly course hours inadequate, and think that the music classes should be elective courses. The obtained findings are considered to contribute to the literature in order to perform the music classes more efficiently.

\section{Suggestions}

Based on the obtained finding, the following suggestions are made:

- Studies, which involve more participants, can be done to determine the attitude of students toward music education in more detail.

- Studies that aim to determine the factors that influence the attitude of students toward music education negatively can be done.

- By doing studies that aim to increase the attitude of primary school students toward music education, the efficiency of the music classes can be increased.

\section{References}

Babacan et al., 2011 - Babacan, E., Babacan, M.D., Pirgon, Y. (2011). Investigation of the attitude of secondary school students toward music education, Selçuk University Ahmet Keleşoğlu Journal of Faculty of Education, 32, 325-336.

Bilgin, Şaktanl, 2008 - Bilgin, S., Şaktanl, S.C. (2008). Selection of Songs for Primary School Music Classes. Mehmet Akif Ersoy University Journal of Faculty of Education, 8(15), 70-80.

Dündar, 2003 - Dündar, M. (2003). Rhythm Education in Pre-school and Primary School Education. GaziUniversity Journal of Gazi Faculty of Education, 23(2), 171-180.

Ergen, Bilen, 2010 - Ergen, D., Bilen, S. (2010). The Effect of Elementary-Level Violin Education Based On Playing With Accompaniment on Intonation, Self-Confidence and Attitude. Western Anatolian Journal of Educational Sciences, 1(1), 23-32.

Gömleksiz, 2003 - Gömleksiz, M.N. (2003). Validity and Reliability of an Attitude Scale on Affective Domain in English Course. Frrat University Journal of Social Science, 13(1), 215-225.

Helvacı, 2012 - Helvacı, A. (2012). A Research Related To Primary School Students' Main Concepts about Music Education and Their Level of Cultural Knowledge. Uluda $\breve{g}$ University Journal of Faculty of Education, 25(2), 531-546.

İnceoğlu, 2010 - İnceoğlu, M. (2010). Attitude Perception Communication. Fifth Edition. Beykent University Press. İstanbul.

Karasar, 2005 - Karasar, N. (2005). Scientific research method. Ankara: Nobel Release Distribution. 
Kırmızıbayrak, 2012 - Kırmızıbayrak, N. (2012). The Evaluation of Music Curriculum In According to Teachers' Opinions (A Sample of Kars Province). Kafkas Üniversitesi Journal of the Institute of Social Sciences, 10, 91-105.

Koca, 2013 - Koca, Ş. (2013). Surveying on Students' Attitudes towards Music Lesson at Secondary School Level. Çukurova University Journal of the Institute of Social Sciences, 22(2), 209-222.

Küçükosmanoğlu, Çakırer, 2012 - Küçükosmanoğlu, H.O., Çakırer, H.S. (2012). The comparison of the Effectiveness of the Accompanying Instruments Used in Teaching Songs in Primary Schools Second Grades. Journal of İdil, 1(3), 48-79.

Kutluk, 2010 - Kutluk, Ö. (2010). Primary Education Pre-Service Teachers' Opinions About Primary Music Courses and Their Self-Confidence About Giving Primary Music Courses. Selçuk University Ahmet Keleşoğlu Journal of Faculty of Education, 29, 289-302.

Levent, Umuzdaş, 2013 - Levent, A., Umuzdaş, S. (2013). The Effect of the Instrument that the Teacher Use on the Attitude towards the Music Lesson. Journal of Research in Education and Teaching, 2(2), 84-88.

Nacakcı, 2006 - Nacakcı, Z. (2006). The Attitude of Elementary School Students towards Music Lessons. National Music Symposium. 26-28 Nisan 2006, Pamukkale University Faculity of Education Denizli.

Noyan, 2012 - Noyan, H. (2012). Investigation of Positive and Negative Influences of Music Lessons on Elementary School Students Regarding the Musical Skills. Master's Thesis. Cumhuriy et University Institude of Educational Sciences. Sivas.

Otacioğlu, 2007 - Otacıoğlu, S.G. (2007). Examination of the Attitudes of the Fifth, Sixth and Seventh Grade Students' Towards Music Course. Dokuz Eylül University Journal of Buca Faculty of Education, 21, 134-139.

Özmenteş, 2006 - Özmenteş, G. (2006). Development of theAttitude Scale towards Music Class. Elementary Education Online, 5(1), 23-29.

Özmenteş, 2012 - Özmenteş, S. (2012). The Relationships between Home Musical Environments, Attitudes towards Music Lessons and Personal Variables of Elementary School Students. Education and Science, 37(163), 53-66.

Rife et al., 2001 - Rife, N. A., Shnek, Z.M., Lauby, J.L., Lapidus, L.B. (2001). Children's satisfaction with private music lessons. Journal of Research in Music Education, 49(1), 21-32.

Şeker, Sayg1, 2013 - Şeker, S.S., Saygı, C. (2013). A Study on Developing a Scale to Determine Classroom Teacher Candidate's Attitudes towards Teaching Music. TurkishStudies, 8(8), $1237 \mathrm{v} 1246$.

Uluocak, Tufan, 2010 - Uluocak, S., Tufan, E. (2010). The Effect of Guitar Use as Teacher's Instrument of Music Class Achievement of Primary School Students. Kastamonu Education Journal, 18(2), 597-606.

Uluocak, Tufan, 2011 - Uluocak, S., Tufan, E. (2011). Examination of the Attitudes of the Sixth Grade Primary School Students' Towards Music Course According to Different Variables. Kastamonu Education Journal, 19(3), 991-1002.

Varış, Cesur, 2012 - Varış, Y.A., Cesur, D. (2012). Correlations between Secondary Education Students' Attitudes towards Music Course and Their Academic Achievement. e-Journal of New World Sciences Academy, 7(4), 318-333.

Yalçınkaya, Eldemir, 2013 - Yalçınkaya, B., Eldemir, A.C. (2013). Development of the Attitude Scale towards Individual Instument Class. Mustafa Kemal University Journal of the Institude of Social Sciences, 10(21), 29-36. 